\title{
$\mathrm{BIM}$ 기반 3차원 모델 라이브러리를 통한 모듈러 교각의 정보모델링
}

\section{Information Modeling of Modular Bridge Pier using BIM Based 3D-Model Library}

\author{
조제헌 ${ }^{1)}$, 김동욱 ${ }^{2)}$, 이광명 ${ }^{3)}$, 남상혁 ${ }^{4}$ \\ Jo, Jae-Hun" ${ }^{1)}$ Kim, Dong-Wook ${ }^{2)} \cdot$ Lee, Kwang-Myong ${ }^{3)} \cdot$ Nam, Sang-Hyeok $^{4)}$ \\ Received December 23, 2013 / Accepted December 31, 2013
}

\begin{abstract}
Modular technology has become a major issue of the construction industries to enhance their productivity. Modular bridge construction generally requires the collaboration between the contractor, designer, fabricator and constructor. Therefore, a readily accessible information model based on BIM technology should be provided for their communication during a construction project life-cycle. In this study, BIM based 3D information modeling was carried out for the modular bridge pier. First, the product breakdown structure (PBS) and level of detail (LOD) of the pier were defined. Based on them, 3D models were created by using parametric modeling method. In addition, database was constructed for the exchange of geometry and property data of 3D models. Finally, application areas of 3D information model were suggested, including the quantity estimation and the 4D simulation.
\end{abstract}

KEYWORDS: BIM, Modular Bridge Pier, Parametric Modeing, 3D Model Library

키워드: BIM, 모듈러 교각, 파라메트릭 모델링, 3차원 모델 라이브러리

1. 서론

\section{1 연구의 배경 및 목적}

최근 국내외 건설시장에서는 다양한 첨단 정보기술을 적용하 여 공기를 단축하고 생산성을 향상시키기 위해 다양한 시도가 이루어지고 있다. 이러한 변화의 흐름에 맞춰 건설시장의 새로 운 패러다임인 BIM(Building Information Modeling) 기술이 도 입되어 건축, 엔지니어링, 건설 산업에서 널리 활용되고 있다. $\mathrm{BIM}$ 기술은 건설 산업의 생산성 향상과 비용 절감 측면에서 큰 효과를 보이며, 여타 산업에 비해 많은 변수와 영향인자를 갖는 건설 프로젝트 특성상 꼭 필요한 기술이다(Eastman et al., 2011). 하지만 대부분의 건설 프로젝트 주체들은 설계와 시공단계에 서 발생하는 많은 정보들을 포함하지 않고 단순히 시각적인 기 능만을 가진 $3 \mathrm{D}$ 모델을 사용하고 있으며, 건설 생애주기 동안 발생하는 무수한 정보들이 체계적으로 관리되지 못하고 있는
실정이다. 이러한 문제점들을 해결하기 위해 건설 프로젝트 생 애주기 동안 발생하는 정보들의 관리 및 활용을 위한 BIM 기반 의 3차원 정보모델 구축 및 활용방안에 대한 연구가 필요하다 (Shim et al., 2010).

Park et al.(2011)은 RC 교각을 대상으로 BIM 기반의 설계 프로세스를 제안하였다. BIM 소프트웨어를 활용하여 $3 \mathrm{D}$ 자동 생성 User Interface를 개발하였으며, 3D 모델과 Database 및 구조 계산서를 연동하여 정보를 유기적으로 연결할 수 있는 정 보 모델의 활용 방안을 제시하였다. Lee et al.(2012)은 콘크리트 박스 거더를 대상으로 BIM기반 교량 정보 모델을 구축하였다. 3차원 파라메트릭 모델링을 통해 다양한 형태의 프리케스트 세 그먼트를 생성하였으며, 이를 기반으로 설계 검토, 간섭체크, 제 작 시뮬레이션이 가능한 정보 모델을 구축하였다. 또한 정보 모 델을 교량 시공 현장에 적용하였으며, 비용과 시간을 절감하는 효과를 얻을 수 있었다.

\footnotetext{
1)학생회원, 성균관대학교 대학원 건설환경시스템공학과 석사 (gjslzja@skku.edu)

${ }^{2)}$ 학생회원, 성균관대학교 대학원 건설환경시스템공학과 석사과정 (id88wooga@skku.edu) (교신저자)

3)정회원, 성균관대학교 대학원 건설환경시스템공학과 교수, 공학박사 (leekm79@skku.edu)

${ }^{4)}$ 정회원, (주)두컴스엔지니어링코리아 대표이사, 공학박사 (ducoms@yonsei.ac.kr)
} 


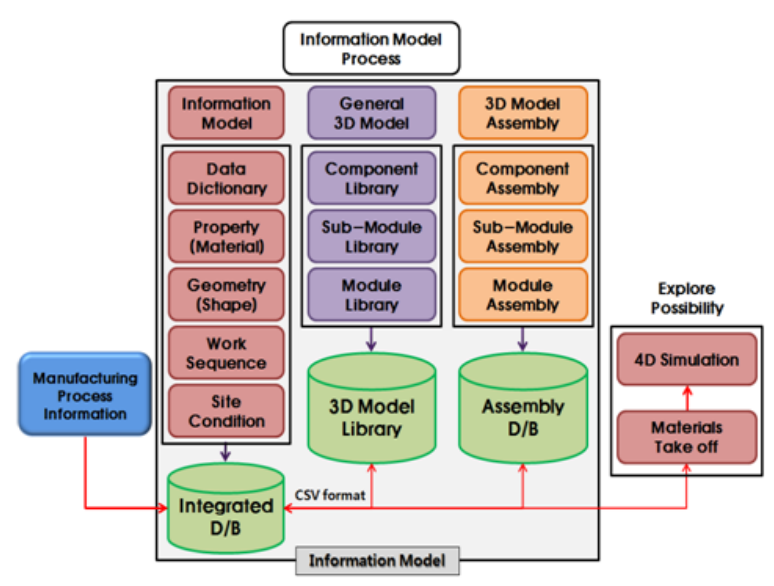

Figure 1 Process of 3D Information Modeling

기존 연구에서는 설계단계 또는 시공단계에서 부분적으로 정 보모델을 활용하였지만 본 연구에서는 조립식 모듈러 교각을 대상으로 설계에서 유지관리에 이르기까지 프로젝트 생애주기 동안 발생하는 정보들의 관리 및 활용을 위한 3차원 기반의 정 보모델을 구축하였다. 또한 Pilot Test를 실시하여 정보 모델의 타당성을 검토하였다.

\section{2 연구 범위 및 방법}

모듈러 교각의 정보모델을 프로젝트 단계별로 다양하게 활용 하기 위해서는 각기 다른 형식의 3 차원 모델과 관련 정보들을 분류, 관리, 저장, 사용할 수 있는 데이터베이스가 요구된다 (Cheon et al., 1999). 따라서 본 연구에서는 모듈러 교각의 표준 부재/모듈에 대한 3차원 모델 라이브러리와 정보모델 데이터베 이스를 구축, 활용하고자 Figure 1과 같은 연구 범위를 계획하였 다. 정보 모델을 구현하기에 앞서 모듈러 교각의 계층구조(PBS, Product Breakdown Structure)와 상세수준(LOD, Level of Detail)을 정의하였으며 Microstation V8i를 이용하여 각 부재의 3 차원 파라메트릭 모델을 작성하였다. 3D 모델을 바탕으로 라 이브러리를 구축하였으며 부재간의 조합 프로세스 정의를 통해 자동 조립 생성 모듈을 개발하였다. 라이브러리에 저장되어 있 는 정보들을 데이터베이스에 저장하여 정보를 통합 관리할 수 있는 모델을 구축하였다.

\section{2. 모듈러 교각}

\section{1 개요}

모듈러(Modular) 기술은 Lego와 같이 사전에 제작된 표준 부재들을 조합하여 전체 시스템을 구성하는 기술로써 모듈의 교체로 시스템에 부가기능을 부여하거나 성능 업그레이드가 가 능한 Plug-in 기술이다. 이러한 모듈러 기술을 교량에 접목하여

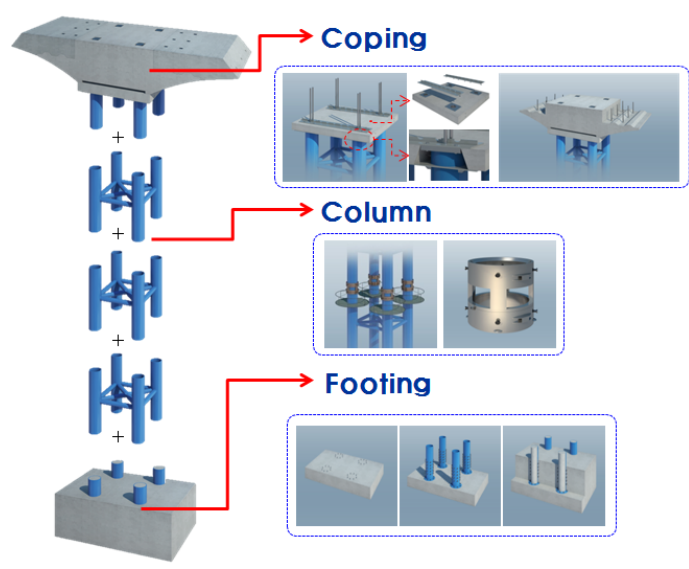

Figure 2 Composition of Modular Bridge Pier

토목 프로젝트의 특성에 맞게 다양한 현장 조건을 반영할 수 있도록 표준 모듈을 조합해, 구조적 안정성, 기능성, 요구수명 등을 확보할 수 있다. 또한 모듈러 교량은 기존의 조립식 교량과 는 다르게, 다양한 현장조건에 대응할 수 있도록 단면, 폭 길이 방향으로 자유 확장되는 표준 모듈들을 사전제작하고 표준 모듈 DB 및 시뮬레이션 프로그램을 이용한 모듈 조합설계를 함으로 써 비용과 시간의 경제성을 확보할 수 있는 기술이다. 또한 일반 적인 교량형식은 다양한 현장조건에 따른 다른 변수를 포함하고 있기 때문에 구조물을 정형화하여 표준화하기에 한계점이 있다. 하지만 Figure 2의 모듈러 교각의 경우 각각 기둥(Column), 코 핑(Coping), 기초(Footing)로 규격화되어 모듈별로 구성되어 있 다. 이러한 모듈러 교각의 조립단계와 부품구조는 정보모델 구 축을 위한 분류체계를 보다 쉽게 표준화하고 정형화할 수 있는 장점을 가지고 있으며, 표준화된 분류체계와 시공 프로세스 정 보를 바탕으로 데이터베이스를 구축함으로써 시공 시뮬레이션 을 위한 정보모델로의 활용이 가능하다.

\section{2 모듈러 교각의 LOD(Level Of Detail) 정의}

국내외 공공 기관에서는 모든 건설 정보들을 체계적으로 분 류하고 통합 데이터베이스를 만들기 위해 다양한 표준 분류체계 를 정의하고 있다. 이러한 분류체계는 구조물의 구성과 특징, 규칙, 활용분야에 따라 분류되어 있으며, 정보교환 및 사용을 목적으로 정의되어 있다. 하지만 이러한 분류체계는 대부분 상 부형식에 제한적으로 적용되고 있으며, 하부형식에 관한 내용은 미비하다(Jo et at., 2012).

따라서 이 연구에서는 Figure 3과 같이 모듈러 교각의 분류체 계와 3차원 모델의 작성을 위하여 LOD(Level of Detail)를 우선 적으로 정의하였다. 프로세스별 요구정보와 BIM 데이터의 표현 수준 및 활용범위를 정의하고, Component, Sub- Module, Module의 3단계로 LOD 300 수준인 모듈러 교각의 3차원 모델 


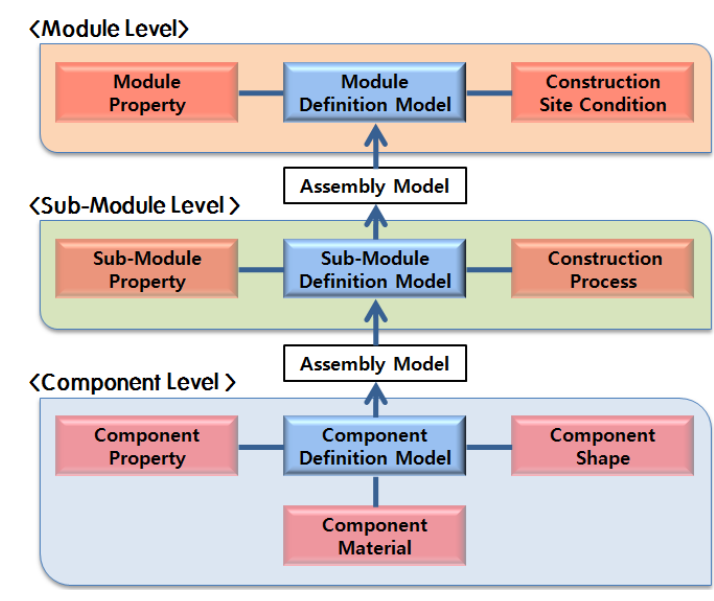

Figure 3 Level of detail for 3D Modeling

의 Level을 분류하였다. 각각의 Level은 Shape, Property, Material, Process, Site condition 등 5가지 영향인자를 바탕으 로 세분화된다. 이러한 $\mathrm{LOD}$ 를 바탕으로 모듈러 교각의 3차원 기반 정보모델을 Component, Segment, Module단위 구조체계 로 정의할 수 있다.

\subsection{PBS(Product Breakdown Structure)}

정의된 $\mathrm{LOD}$ 를 바탕으로 모듈러 교각의 구성을 정형화, 표준 화시켜 Top-down 방식으로 구조물 계층구조(PBS, Product Breakdown Structure)를 작성하였다. 구조물의 분류체계는 부 품과 부품사이의 모자관계(Parent-Child Relationship)를 규정 하고 구조물 전체의 구조를 구성하게 된다. Figure 4는 모듈러 교각을 구성하는 module과 segment에 대한 분류체계를 나타 내고 있다. 모듈러 교각 3차원 모델은 모델 구성의 상위단위인 기둥(Column), 코핑(Coping), 기초(Footing)의 3그룹의 Submodule 단위로 나뉜다.

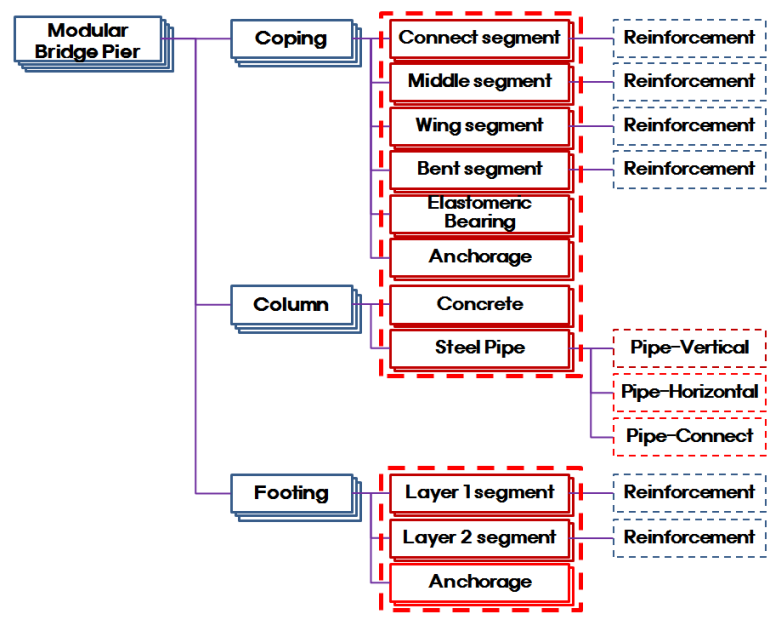

Figure 4 PBS of Modular Bridge Pier

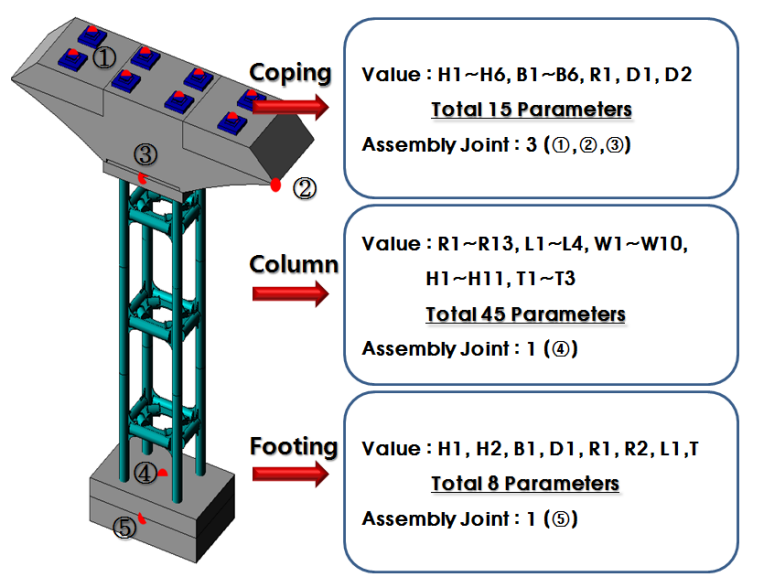

Figure 5 Selection of Parameters and Relation of Restriction

코핑은 Connect, Wing, Middle, Bent 세그먼트와 탄성받침, 정착장치로 분류되며 기둥과 기초는 하위 레벨인 콘크리트 블 록, 정착장치, Steel Pipe 등의 Component level로 세분화된다. 또한 모델의 $\mathrm{PBS}$ 를 바탕으로 교각의 부품별 형상변수와 구속관 계의 파라미터를 Figure 5 와 같이 최소 단위로 정의하였다. 변 수는 중복이나 연산에 의해 정의되는 것을 제외한 순수 입력변 수와 치수 변화에 따른 전체적인 형상과 조립관계가 유지되기 위한 구속조건(Fix Point)을 포함한다(Kim et al., 2007). 결과적 으로 코핑과 기둥, 기초의 입력변수의 개수는 각각 15-3개 45-1 개, 8-1개이며 구속조건의 개수는 3 개 1 개, 1 개이며 정착 장치의 입력변수 24 개와 구속조건 개수 2 개를 더해 총 92 개의 변수와 7 개의 구속조건을 가진다.

\section{3차원 모델 라이브러리}

\section{1 파라메트릭(Parametric) 모델}

2.3절에서 정의한 부재의 파라미터와 구속관계를 바탕으로 파라메트릭 디자인 방법론을 사용하여 모듈러 교각을 모델링하 였다(Sacks, 2004). 앞에서 정의한 Component 단위의 11 개 Segment와 Part 단위의 3차원 객체에 Microstation V8i DDDesign 기능을 이용한 파라메트릭 모델링을 수행하였다. 일반적으로 Microstation에서 요소는 자체의 속성에 의해 치수가 제어된다. 그러나 기하학적 제약과 제약 매개 변수를 통해 요소를 치수에 연결할 수 있다. 즉, 치수 값을 변경하면 업데이트된 치수 값과 의 관계를 유지하기 위해 요소가 바뀌게 된다. 이와 같은 방법으 로 기본 2차원 단면 작성 시 접선, 직각, 평행 또는 각도 고정을 통해 기하학적 제약을 부여하고, 선정된 parameter들을 입력함 으로써 파라메트릭 단면을 생성한다. 최종적으로 $2 \mathrm{D}$ 파라메트 릭 단면에 Distance를 설정하여 수치변화에 따라 3 차원 객체가 변화하는 3D 파라메트릭 모델이 완성된다(Jo et al., 2012). 이렇 

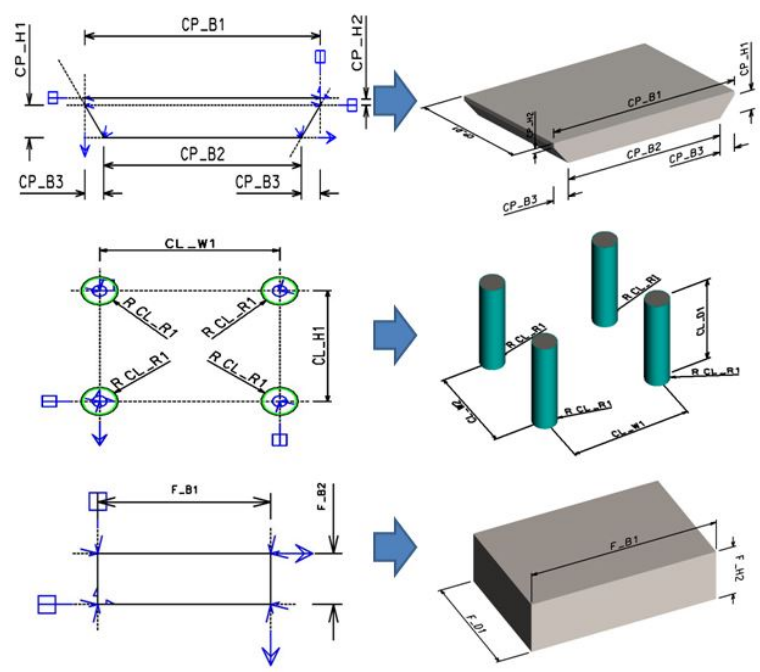

Figure 6 Parametric 3D Models of Component Level

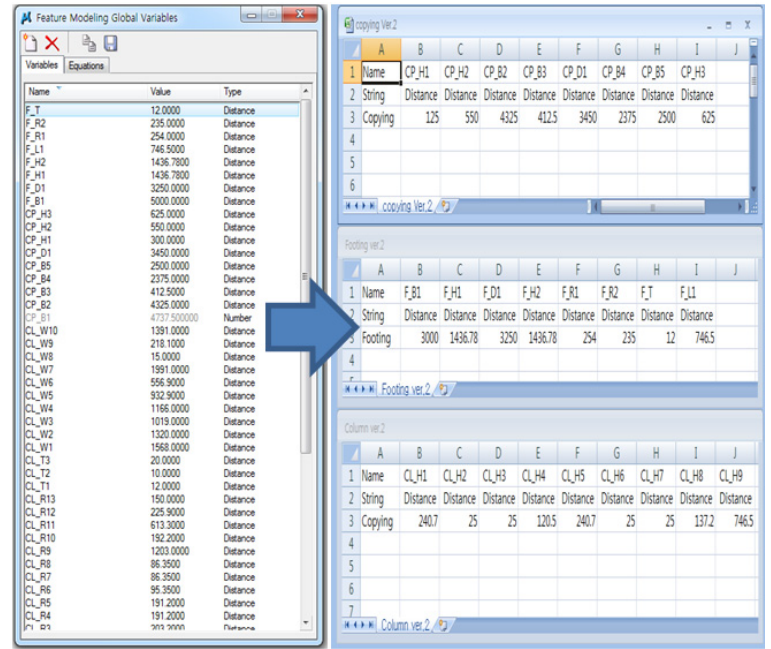

Figure 7 Geometry Information Extraction

게 생성된 3차원 모델은 Figure 6과 같으며, Figure 7과 같이 CSV 파일로 형상정보를 추출할 수 있다.

\subsection{3차원 Cell 모델 라이브러리}

모듈러 교각의 3차원 모델을 다음 Figure 8과 같이 Cell Library로 구축하였다. Cell 라이브러리 기능은 특정 3차원 객체 에 구속점(Fix point)을 정의하여 라이브러리로 보관하는 기능으 로 쉽게 3차원 모델의 재사용이 가능하다. 또한 불러 들여온 객 체는 라이브러리로 변환되기 전에 가지고 있던 파라메트릭 정보 와 기능이 그대로 유지되어 쉽게 객체의 형상 변경이 가능하다. 3차원 객체를 재사용할 경우 미리 지정하였던 구속점을 기준으 로 위치시킬 수 있으며 손쉽게 사용자가 컨트롤할 수 있다. 이러 한 3차원 모델 라이브러리는 사용 목적에 따라 Module 단위, Sub-Module 단위, Component 단위로 라이브러리를 사용자

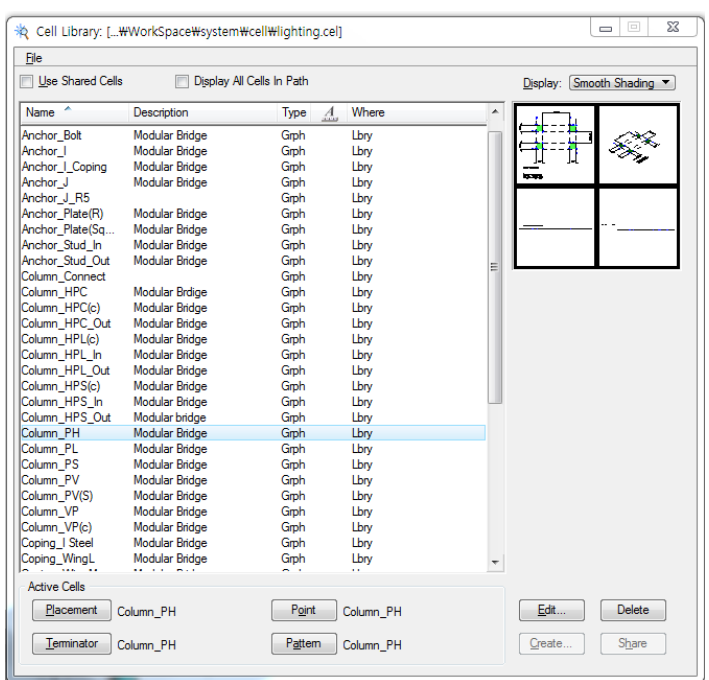

Figure 8 3D Cell Model Library

임의에 따라 구축할 수 있다. 이 연구에서는 Sub-Module 단위 와 Component 단위 라이브러리를 적용하였다. Cell 라이브러 리 파일은 *. ${ }^{*}$ cel 파일 포맷으로 저장되며, 사용자간 손쉽게 정보 교환이 가능할 뿐만 아니라 기존의 Microstation 파일인 *.dgn 파일 포맷보다 훨씬 적은 용량으로 3차원 모델을 저장 및 활용 할 수 있는 장점이 있다.

\subsection{3차원 모델 조합 인터페이스}

모듈러 교각의 3차원 모델 조합모듈을 개발하기 위해 3.2절 에서 구축한 Sub-Module 단위 Cell 라이브러리의 객체의 구속 점을 기준점으로 하는 조합 관계를 Figure 9와 같이 테이블로 정의하였다. 이 조합관계식에서 누적 높이인 $a+b+c^{*} N+d$ 는 교 각의 높이가 되며, 기준점의 높이는 각각의 Sub-Module Cell 모델이 3차원 공간에 위치하게 되는 Z(높이)방향 값이 된다. 여 기서 변수 $\mathrm{a}, \mathrm{c}, \mathrm{d}$ 는 Footing, Column, Coping 객체의 높이 값이 되며, 이는 상부형식에 따라 일정하게 고정된 변수 값이다. 모듈 러 교각은 교량 상부형식에 따라 전체 형상은 유지되며 각각의 부품 치수만 변하게 되므로 상부형식이 정해진다면 이 변수들은

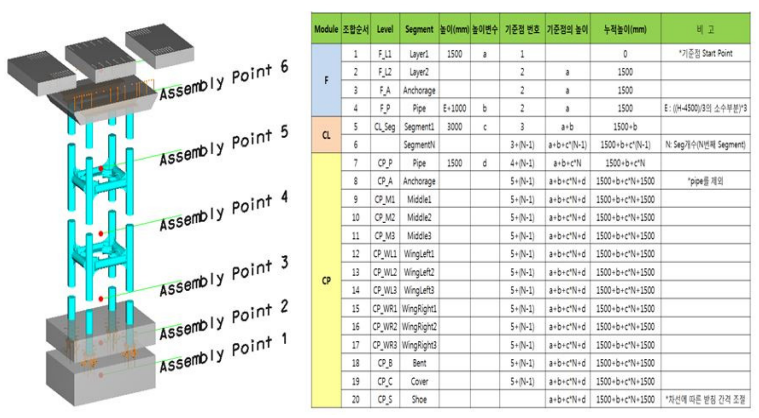

Figure 9 Definition of Assembly Information 


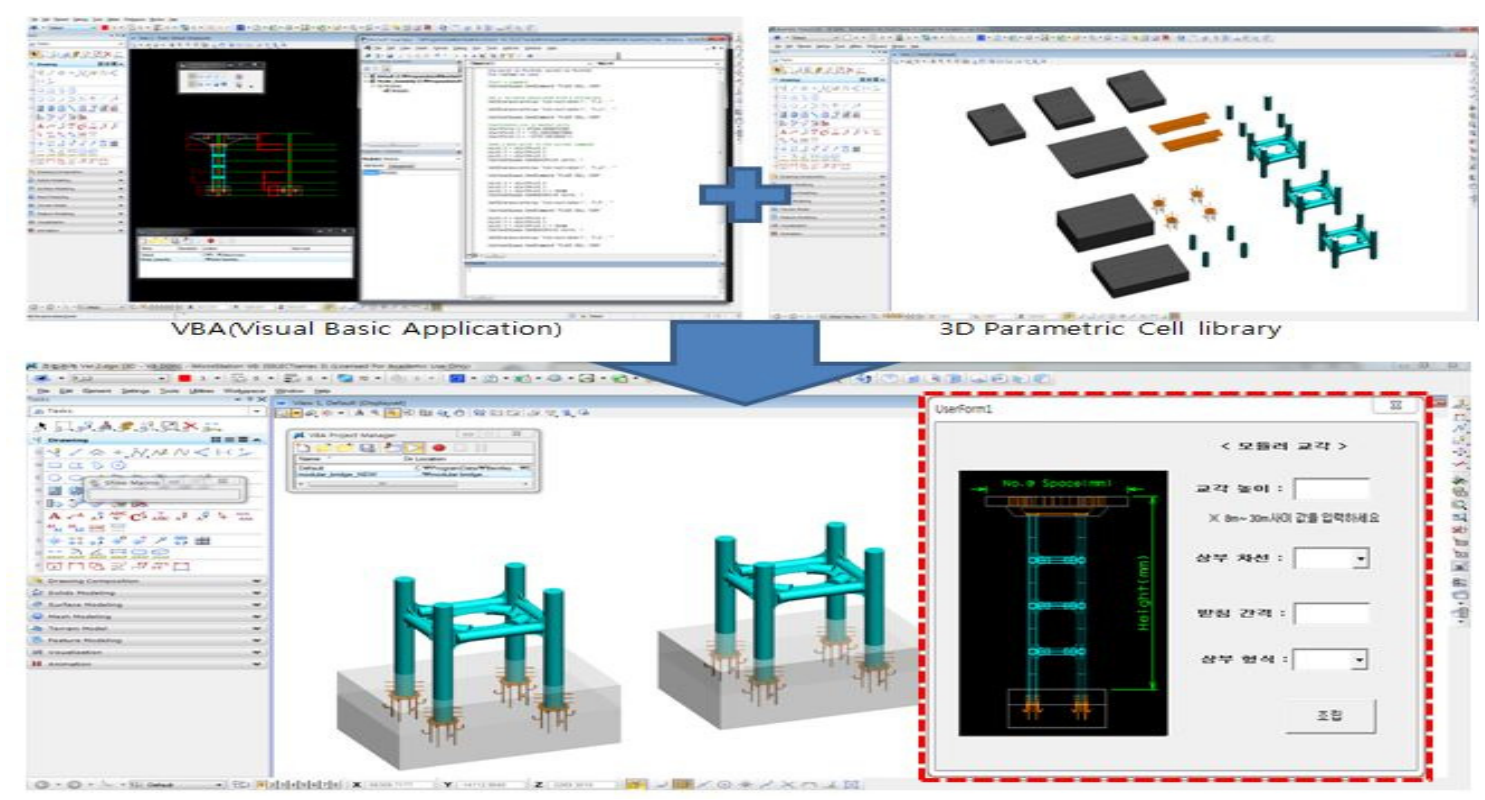

Figure 10 Automatic Combination Module by Assembly Information

항상 일정한 값을 가지게 된다. 또한 변수 $\mathrm{E}, \mathrm{N}$ 은 각각 Key Segment와 Column module 개수를 의미하며, 교각의 높이에 따라 변하는 값으로 정의하였다. Key Segment는 기둥과 기초 를 연결하는 Steel Pipe로 전체 교각의 높이에서 고정된 a, c*N, $\mathrm{d}$ 값을 제외한 나지 값으로 정의하였다.

Figure 10은 Visual basic application과 Cell 라이브러리를 통해 완성된 조합 인터페이스를 보여주고 있다. Column module 개수는 입력된 교각 높이에 따라 자동으로 계산되며 개수를 팝 업창으로 몇 개의 Column module이 조합되는지 나타나게 하였 다. 교각은 Footing의 중심을 기준으로 높이가 계산되어 조립되 며 Cell library에 저장된 Sub-module의 구속점은 모두 Footing 의 중심에서 시작하는 수직선 위에 있어 기준점의 Z값(높이)만 변수로 설정하면 X,Y 좌표값 입력 없이 조립될 수 있게 하였다. 또한 상부의 도로차선 수에 따라 2차선에 1교각으로 정의하였으 며, 상부형식이 4차선 이상일 때 해당 높이 값은 동일하게 $1,000 \mathrm{~mm}$ 의 X좌표 값을 가지게 되면서 Wing Segment 대신 연 결용 Bent Segment가 들어가게 된다. 마지막으로 탄성받침대 는 교각상부 높이 기준으로 간격 및 개수에 따라 균일하게 위치 값을 갖게 된다. 이렇게 정의된 조합관계식을 통해 프로그램에 서 제공하는 VBA(Visual Basic Application)와 매크로 기능을 사용하여 모델 조합 인터페이스를 개발하였다. 이 조합 모듈은 사용자가 인터페이스 창에서 교각의 높이, 상부차선, 받침간격, 형식 등의 조건을 입력하거나 선택하면, 조합 관계식에 따라 Cell 라이브러리에서 해당객체를 불러들여 자동으로 모듈러 교 각의 3 차원 모델을 생성한다.

최종적으로 완성된 모델 조합 인터페이스를 통해 조합관계식

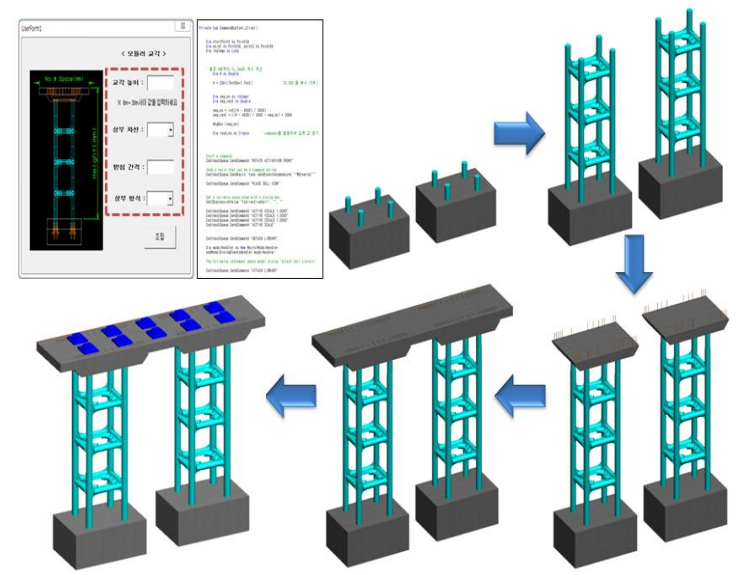

Figure 11 Verification of Automatic Combination Module

과 라이브러리의 타당성을 검토하였다. 검증 대상은 교각 높이 $12 \mathrm{~m}$, 편도 2차선, 받침간격 $2.3 \mathrm{~m}$, 상부형식 PSC 연속교로 설정 하였으며, Figure 11과 같이 교각이 정상적으로 조립됨을 확인할 수 있었다.

\section{4. 정보모델 구축 및 활용}

\section{1 정보모델 구축 계획}

정보모델이란 "대상을 구성하고 있는 요소들의 정의, 관계, 제약조건, 형상, 속성, 특징 등의 정보들을 포함하고 이러한 정 보들을 교환하고 사용할 수 있는 모델"로 정의할 수 있다. 이와 같이 모듈러 교각의 정보모델을 구축하기 위해서 교각을 구성하 는 모듈의 정의와 분류체계를 바탕으로 형상, 속성, 조립관계 
등의 정보를 정의하였으며(Alfares and Seireg, 1996), 정보모 델의 활용범위를 아래와 같이 선정하였다.

(1) 3차원 모델 변수를 활용한 부품의 규격화

(2) 파라메트릭 모델을 활용한 설계의 시각화

(3) 정보모델을 활용한 물량산출 및 견적

(4) $4 \mathrm{D}$ 시뮬레이션 기능을 이용한 시공성 검토

(5) DBMS를 이용한 정보의 관리, 교환 및 활용

정보 사전 및 속성정보, 형상정보, 작업공정, 현장조건 등의 정보는 제작과정 정보와 함께 통합 데이터베이스에 저장하고, Level 별 3차원 모델 라이브러리의 형상정보과 조합관계 정보 를 통합 데이터베이스와 연동하는 프로세스를 계획하였다.

\section{2 정보모델 데이터베이스 구축}

본 연구에서는 정보모델에 필요한 형상정보, 속성정보 조립 관계의 특성을 검토하여 정보모델 데이터베이스 구축에 적합한 모델로서 관계형 데이터베이스를 활용하였다. 여러 관계형 데이 터베이스 프로그램 중 MS Access를 사용하여 DBMS(Database Management System)를 구축하였다. MS Access는 다른 DBMS 에 비해 사용이 편리하고 특히 Excel과의 호환성이 높으며, 다양 한 프로그램과의 데이터 자동 연동이 가능한 확장성을 가지고 있다. 데이터베이스를 구축하기 위해서는 모듈러 교각을 대표하 는 segment의 모형화와 정보의 흐름을 분석하여 데이터베이스 구조를 결정하여야 한다.

Figure 12는 모듈러 교각의 데이터베이스 구조를 보여주고 있다. 3차원 모델 라이브러리를 통해 각각의 segment에 포함되 는 형상정보와 속성정보를 CSV(Comma Separated Value) 포

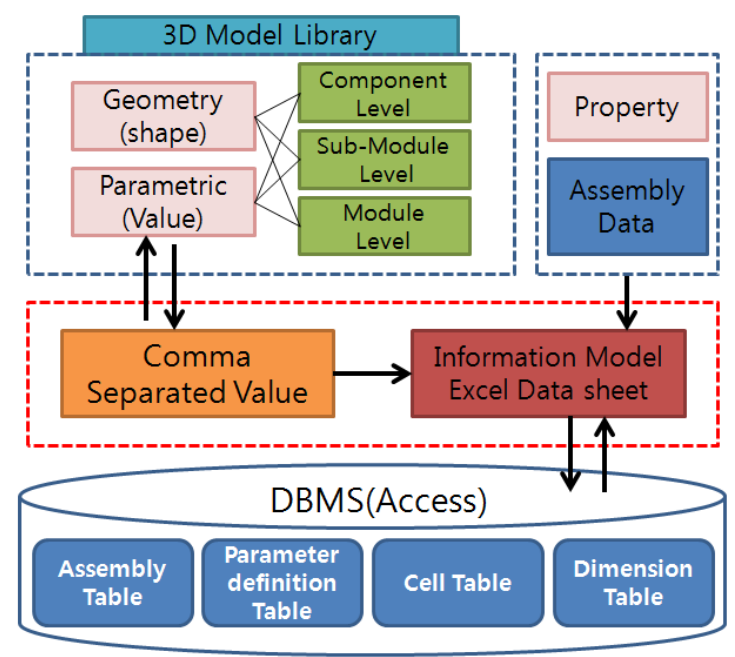

Figure 12 Construction Plan of Database
맷의 파일로 export하여 정보모델 Excel Data Sheet에 저장하 게 된다. CSV파일은 Sub-module단위로 분류되어 형상 정보들 을 가지며, 이 정보들은 다시 3D CAD Tool에 Import되어 변경된 형상정보들이 자동으로 $3 \mathrm{D}$ 객체에 적용된다. 3 차원 모델 정보 는 CSV 파일을 통해 데이터베이스와 3D CAD Tool 양방향으로 정보교환이 가능하다. 이어서 조립관계에 관한 정보는 Excel 파 일 기반으로 Excel Data Sheet에 바로 입력되게 된다. 입력된 정보들은 Excel Sheet 단위로 MS Access의 테이블에 연동되 며, 데이터 업데이트 시 DBMS에서 자동으로 반영된다. 데이터 베이스는 기본적으로 Table 형식으로 구성되며, 본 연구에서는 조립관계, 변수(Name), Cell(모델정보). 형상정보의 4가지 Table 로 데이터베이스를 구축하였다. 또한 MS Access와 Excel의 좋 은 호환성을 바탕으로 정보의 교환 및 업데이트가 쉽고 빠르게 이루어져, 향후 추가로 발생하는 정보들에 대한 충분한 확장성 을 가지도록 구축하였다.

이러한 데이터베이스는 Figure 13과 같이 Cell Table과 Design Table 두 가지로 나누어 구축하였다. 11 개의 Cell 테이블은 Sub-module 단위 별로 3차원 모델 라이브러리의 모델번호 (Object ID), 그룹정보(Cell), 부품정보(Component), 변수정보 (Length), 수치 값(Value), 개수(Number) 등의 6가지 정보를 포 함하고 있으며, Design Table은 Assembly, Parameter, Geometry 로 구분하여 모듈러 교각의 조립관계 및 분류체계, 변수정보 등 의 속성정보를 포함한다. 또한 데이터베이스 정보의 중복과 업

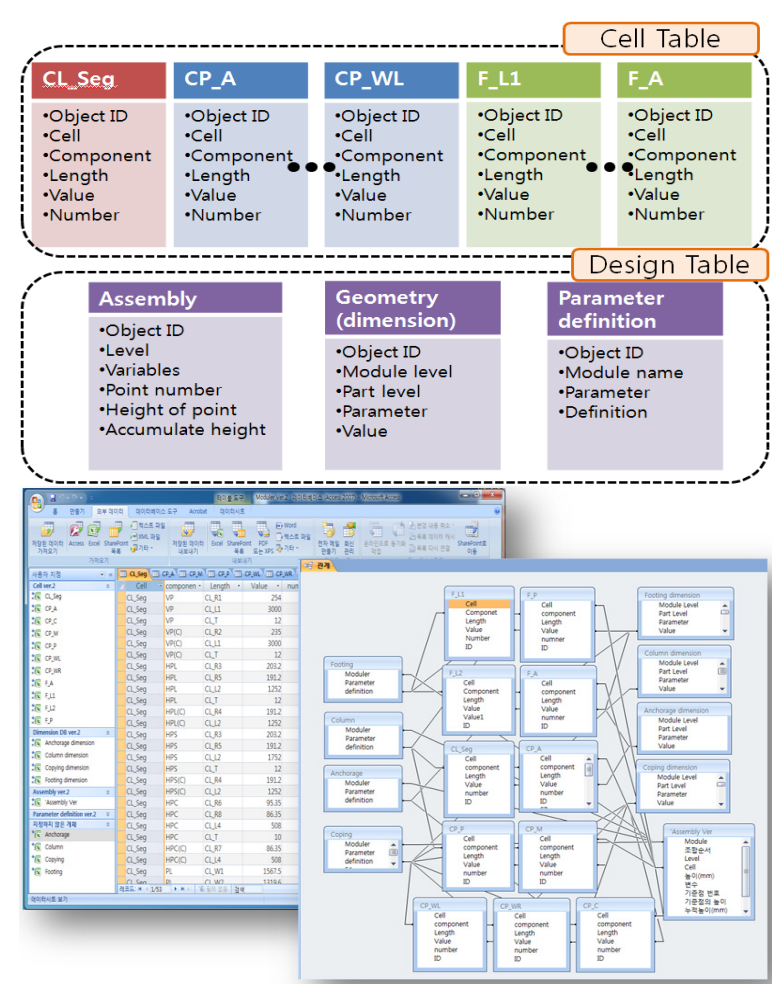

Figure 13 Configuration and Interrelation of Database

16 Journal of KIBIM Vol.3, No.4 (2013) 


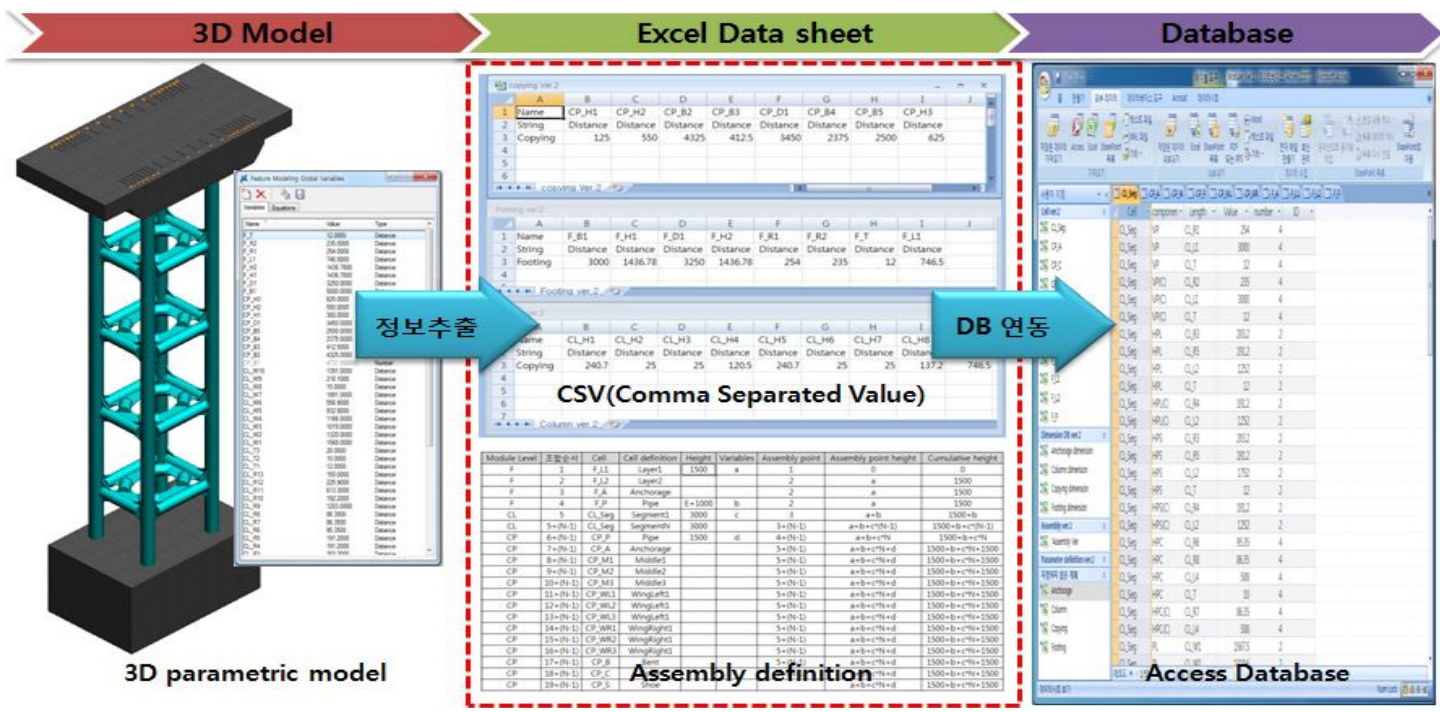

Figure 14 Examination of Information Model Database

데이트 오류 방지를 목적으로 Table간 상관관계를 정의하고 관 련된 정보는 자동으로 업데이트되도록 데이터베이스를 통합하 였다. 결과적으로 앞에서 정의한 11 개의 Cell Table에 조합모듈 인터페이스 조건에 따라 생성된 3차원 모델의 정보 값을 입력하 면, 미리 정의된 상관관계에 따라 Design Table의 정보들이 자 동으로 업데이트된다.

완성된 정보모델 데이터베이스의 연동성을 Figure 14와 같이 검증한 결과 $3 \mathrm{D}$ model의 형상 및 속성정보와 $\mathrm{DB}$ 와의 상호 연동 성을 확인하였으며, 일부 중복되는 형상 변수들을 수정하였다. 따라서 이러한 데이터베이스를 통해 관련 정보의 확장성과 활용 성이 증대될 것으로 기대된다.

\section{3 정보모델 활용방안}

\subsection{1 물량산출}

3D model library의 Module, sub-module, component 단위 의 형상 정보와 조합 모듈을 통해 생성된 3D model을 이용하여 Figure 15와 같이 모듈러 교각의 전체 물량을 Microstation V8i

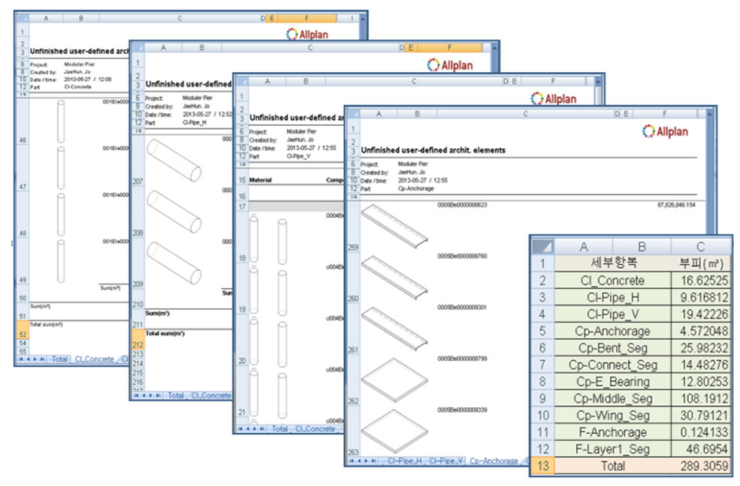

Figure 15 Quantity Estimation by 3D CAD
의 .dgn 파일을 Allplan으로 Export하여 추출하였으며 연계 과 정에서 일부 속성정보의 손실을 확인하였다. 정보모델을 이용한 물량산출은 특정 부재의 일부 영역을 3D model library에서 불 러와 물량을 확인할 수 있는 장점이 있다. 이는 설계단계부터 정확한 물량 산출을 가능하게 하여 동일 업무 반복을 최소화할 수 있다. 또한 이러한 물량 산출서는 사용자가 임의대로 양식의 수정이 가능하며, Excel, PDF 등 다양한 포맷으로 출력 또한 가능하다. $3 \mathrm{D} \mathrm{CAD} \mathrm{Tool}$ 을 활용한 물량 산출은 기존의 $2 \mathrm{D}$ 도면 으로부터 물량을 산출하는 방식에 비해 작업시간이 훨씬 절약되 며, 동시에 더욱 정확한 산출이 가능하고 경제적, 효율적인 장점 이 있다(Shim et al., 2011).

\subsubsection{D 시뮬레이션}

Microstation V8i의 Animation Producer Dialog 기능을 이용 하여 Figure 16과 같이 4D 시뮬레이션을 수행하였다. 통합 데이 터베이스의 Work Sequence 정보를 바탕으로 인터페이스를 통 해 작업 단위 Time Schedule를 작성하고 각각의 작업 단위에 해당하는 3차원 모델 객체를 연결하여 시간별 공정 작업을 확인

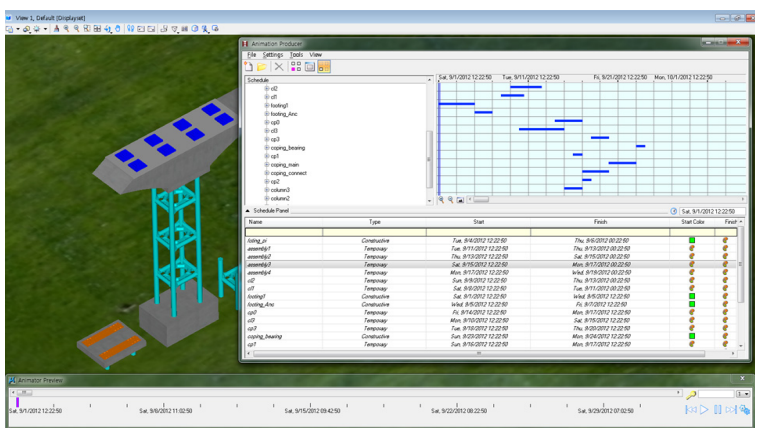

Figure 16 4D Simulation using Time Schedule Function 
할 수 있는 4D 시뮬레이션을 수행하였다. 작업타입은 Constructive, Destructive, Permanent, Temporary로 정해지며, 가시설과 건 설장비 사용 등의 효과를 적용할 수 있다. $4 \mathrm{D}$ 시뮬레이션은 공사 일정을 한눈에 파악이 가능하며 시공성을 판단할 수 있는 자료 가 된다(Lee et al., 2012). 또한 인터페이스에서 제작한 Time Schedule 표는 MS Project나 Primavera 등의 공정관리 프로그 램과 호환이 되어 시각적인 효과 이외에도 공정에 관한 정보를 재사용할 수 있다는 장점이 있다.

\section{5. 결론}

본 논문에서는 경제성과 기술 경쟁력의 장점을 가진 조립식 모듈러 교량의 교각을 대상으로 분류체계를 선정하고 정보모델 을 구축함으로써 실제 프로젝트 단계에서 정보를 관리하고 활용 할 수 있는 방안을 제시하였다. 이 연구를 통해 도출된 주요 연구 결과를 요약하면 다음과 같다.

(1) 모듈러 교각의 3 차원 모델링과 정보화 작업을 위해 선정된 $\mathrm{LOD}$ 와 PBS를 바탕으로 표준모듈과 변수를 선정하고, 파라 메트릭 디자인 방법론을 적용한 3차원 Cell 모델 라이브러리 를 구축하였다.

(2) 표준 모듈간 조합관계를 정의하여 VBA을 사용한 조합모듈 인터페이스를 개발하였으며, 이 조합모듈을 통해 입력 조건 에 따라 3차원 모델의 자동생성이 가능하며, 수치변화를 용 이하게 하였다.

(3) 정보모델 데이터베이스의 구축 및 활용 계획을 바탕으로 모듈 러 교각의 형상, 속성, 조립관계, 분류체계 등의 다양한 정보를 포함하고 확장 및 활용 가능한 데이터베이스를 구축하였다.

(4) 물량산출과 $4 \mathrm{D}$ 시뮬레이션을 통해 프로젝트의 설계 및 시공 단계에서 모듈러 교각의 정보모델 활용 가능성 및 타당성을 확인하였다.

(5) 모듈러 교각의 정보모델 구축을 통해 교량 하부구조의 정보 모델 구축 및 활용 방안을 제시하였으며, 이를 통해 향후 다 양한 조립식 교량에 확대 적용 가능 할 것으로 판단된다.

\section{감사의 글}

본 연구는 국토교통부/국토교통과학기술진흥원 건설기술연 구사업의 연구비지원(10기술혁신B01-직선교량의 공사기간 단 축을 위한 표준모듈 활용 조립식교량 기술개발 연구단)에 의해 수행되었으며, 본 연구를 가능케 한 국토교통부 및 국토교통과 학기술진흥원에 감사드립니다.

\section{REFERENCES}

Alfares, M. and Seireg, A. (1996), “An integrated system for computer-aided design and construction of reinforced concrete buildings using modular forms", Automation Construction, Vol. 5, pp. 323-341.

Cheon, J-H, Jeong, Y-C, Lee, B-H (1999), “A Research on the Proposal and Implementation of Database Model for an Integrated Structural Design Systems", Journal of the Architecture Institute of Korea, Vol. 15, No. 7. pp. 11-22.

Eastman, C., Teicholz, P., Sacks, R. and Liston K. (2011). BIM Handbook: A Guide to building information Modeling for Owner, Managers, Designers, Engineers and Contractor, $\left(2^{\text {nd }} e d\right.$.) JohnWiley\&Sons.

Jo, J-H, Lee, K-M, Nam, S-H (2012), "Parametric Modeling of Modular Bridge Pier", Proceedings of KIBIM Annual Conference, Vol. 1 No. 1, pp. 59-60.

Jo, J-H, Lee, K-M, Nam, S-H (2012), "Classification Scheme of Modular Bridge Pier for Information Modeling", Proceedings of the Society of CAD/CAM Engineering Conference.

Kim, M-S, Lee Y-B, Lee K-M, Park, Y-H, Park M-S (2007),

"A Study on the Application of 3-D Parametric Modeling Method to Prestressed Concrete Box Girder Bridges", Proceedings of Korean Society of Civil Engineering Convention, pp. 3460-3463.

Lee, K-M., Lee, Y-B, Shim, C-S. (2012), "Bridge information models for construction of a concrete box-girder bridge", Structure and Infrastructure Engineering, Vol. 8, No. 7 , pp. 687-703.

Park, N-Y, Jo, J-H, Lee, K-M (2011), "A study of the BIM-based Design Process of Reinforced Concrete Bridge Columns", Proceedings of KIBIM Annual Conference, Vol. 1 No. 1, pp. 41-42.

Sacks, R. (2004) "Parametric 3D modeling in building construction with examples from precast concrete", Automation in Construction, Vol. 13, pp. 291-312.

Shim, C-S, Lee, K-M, Kim, Y-H, Hwang, G-H (2010), "Life-cycle Management of High-speed Railway using 3D Railway Infrastructure Information Models", Journal of The Korean Society for Railway, Vol. 13, No. 2, pp. 30-38. Shim, C. S., Yun, N. R. and Song, H. H. (2011), “Application of 3D Bridge Information Modeling to Design and Construction of Bridges", Procedia Engineering, 14, pp. 95-99. 